\title{
PEMANFAATAN PRODUK HASIL SAMPING IKAN BAJI - BAJI (Grammoplites scaber) SEBAGAI TEPUNG YANG BERGIZI BERBASIS "ZERO WASTE CONCEPT"
}

\author{
Ayu Diana1, Muhammad Zakiyul Fikri² \\ Program Studi Teknologi Pengolahan Hasil Perikanan, Politeknik \\ Tanjungbalai \\ Jl. Sei Raja Kelurahan Sei Raja Kecamatan Sei Tualang Raso Kota \\ Tanjungbalai, Indonesia \\ Email: ayudianatip2012@gmail.com
}

\begin{abstract}
The processing of Grammoplites scaber as a whole by utilizing the processed products will provide more benefits such as reducing waste management activities. The research objective is to increase the potential of baji-baji fish by conducting continuous studies through the use of byproducts as flour against its nutritional content, as well as optimally utilizing it through zero waste concept. The research method used was an experimental method and experimental design in the form of a not factorial complete random design in 3 treatments (head, stomach contents, skin). The principle of zero waste concept by handling waste byproducts by utilizing optimally and yield becomes a parameter in the most important thing to know the economic value and effectiveness of a product process. Based on the test results it is known that the percentage of baji-baji fishes for waste byproducts is $76 \%$ compared to meat $24 \%$, the largest byproducts are found in the head bones $(47 \%)$ and skin $(18 \%)$ and stomach contents in the body $(11 \%)$ ). Yields on flour making are Head (71\%), stomach contents (9\%), and skin (20\%). The best chemical composition of flour is Protein 65,377\% (head flour), water content 4,509\% (skin flour), fat 13,463\% (skin flour), ash content 2,204\% (head flour), and carbohydrates 22,208\% (stomach contents). Therefore the $76 \%$ baji-baji fish by-product can be used as raw material for making flour and has a good nutritional content.
\end{abstract}

Keywords: Baji-baji fish, Flour, Proximate.

\section{A. PENDAHULUAN}

Ikan baji-baji (Grammoplites scaber) merupakan jenis ikan tangkapan nelayan yang dijual lokal. Ikan ini banyak terdapat di Kota Tanjungbalai Sumatera Utara. Ikan baji-baji ini memiliki habitat di daerah berlumpur, morphologi tubuh berwarna kecoklatan gelap dengan rupa jelek dan bau amis yang membuat sebagian besar masyarakat lokal kurang meminati dan mengenal ikan ini, untuk itu perlu upaya penanganan dan pengkajian tentang ikan baji-baji agar dapat dikenal dan diminati oleh masyarakat. Menurut Nurjanah (2011) menjelaskan bahwa ikan merupakan salah satu sumber zat gizi penting bagi proses kelangsungan hidup manusia. Manusia telah memanfaatkan ikan sebagai bahan pangan sejak beberapa abad yang lalu. Sebagai bahan pangan, ikan mengandung zat gizi utama berupa protein, lemak, vitamin dan mineral.

Berbagai penelitian tentang ikan sebagai makanan berprotein yang baik untuk kesehatan yang mampu meningkatkan nilai komersil ikan telah banyak dilakukan berbagai pengujian terutama pada komposisi kimia dan kandungan gizi ikan. Ikan memegang peranan penting dalam pemenuhan sumber gizi dan keamanan hidup bagi manusia pada negara berkembang (Gandotra et al., 2012).

Menurut Pamijiati menjelaskan juga bahwa ikan banyak digemari oleh sebagian besar masyarakat Indonesia karena memiliki kandungan gizi tinggi dan protein yang lengkap dan penting untuk tubuh Ikan jenis apapun akan banyak digemari oleh sebagian besar 
masyarakat karena memiliki kandungan gizi tinggi dan protein lengkap yang diperlukan oleh tubuh.

Kajian tentang pemanfaatan ikan baji-baji ini merupakan penelitian yang saling terkait dan berkelanjutan dengan penelitian sebelumnya yaitu tentang "Peningkatan Potensi Ikan Baji-Baji Sebagai Sumber Bahan Baku Produk Pangan". Hasil penelitian tersebut menjelaskan bahwa ikan baji-baji memiliki komposisi kimia yang baik dengan kandungan protein $15,45 \%$ dan juga memiliki kandungan asam amino lisin, methionine, asam aspartate, arginine, serin, sistein yang lebih tinggi dibanding ikan gabus dan ikan bandeng (Diana, 2018).

Pemanfaatan ikan baji-baji secara menyeluruh dengan memanfaatkan hasil olahannya akan memberikan keuntungan lebih seperti mengurangi aktivitas penanganan limbah. Peningkatan potensi ikan baji-baji dengan melakukan pengkajian secara berkelanjutan terhadap kandungan gizinya, serta memanfaatkan secara optimal ikan baji-baji melalui zero waste concept.

Penerapan prinsip zero waste menurut Widyatami (2016) menjelaskan bahwa produk hasil pertanian seluruhnya dimanfaatkan dengan menggunakan teknologi terintegrasi sehingga tidak menghasilkan limbah. Adapun manfaat dan keuntungan penerapan prinsip zero waste adalah: 1 . meningkatkan produktivitas, 2. mengatasi pencemaran lingkungan, 3. meningkatkan pendapatan dan efisiensi. Sulaeman (2008) menjelaskan penerapan konsep zero waste akan memberikan keuntungan dan mengurangi aktivitas penanganan limbah. Berdasarkan itu pemanfaatan ikan baji baji sebagai sumber bahan baku yang memiliki kandungan gizi yang baik perlu dilakukan dengan konsep zero waste. Melalui pengkajian ini mampu meningkatkan potensi ikan ini menjadi produk pangan dengan kandungan gizi terbaik, mendapatkan keuntungan yang maksimal dan efisien, mengurangi aktivitas penanganan limbah dan peningkatan nilai komersil terhadap ikan baji-baji.

Seluruh bagian tubuh ikan baji-baji merupakan komponen organik yang masih dapat dimanfaatkan secara optimal sebagai sumber bahan pangan hewani. Limbah hasil samping (by-product) selama ini hampir sebagian besar terbuang ke pembuangan sampah dan dikubur. Limbah hasil samping ini belum dimanfaatkan dengan baik terutama pada bagian non edible portion yaitu kepala, isi perut, dan kulit. Dengan prinsip menerapkan konsep "zero waste", maka seluruh bagian dari ikan baji-baji ini dapat diolah dengan baik tanpa adanya sisa yang terbuang. Salah satu pemanfaatan limbah hasil samping ini yang dapat dilakukan yaitu mengolahnya menjadi tepung. Menurut Mulia (2004) Tepung tulang dapat juga dimanfaatkan dalam pembuatan mie kering. Berdasarkan hal tersebut limbah hasil samping dapat dimanfaatkan secara optimal sesuai dengan konsep zero waste menjadi tepung, maka dari itu perlu adanya pengkajian lanjut tentang proporsi seluruh bagian limbah hasil samping ikan baji-baji sebagai tepung terhadap kandungan komposisi gizinya.

\section{B. METODOLOGI}

Bahan dan Alat

Bahan yang digunakan adalah ikan baji - baji (Grammoplites scaber), es balok, aquades, aqua bides, CuSO4, indikator metil merah, indikator Brom Cresol Green, K2SO4, larutan H3BO3, larutan $\mathrm{HCl}$, larutan $\mathrm{H} 2 \mathrm{SO} 4$ pekat, larutan $\mathrm{NaCl}, \mathrm{KOH}$, asam asetat glasial, kloroform, larutan $\mathrm{KI}, \quad \mathrm{Na}_{2} \mathrm{~S}_{2} \mathrm{O}_{3}$, indikator phenolptalein, Heksana, Alkohol 96\%, Asam Sulfat $\left(\mathrm{H}_{2} \mathrm{SO}_{4}\right)$, Natrium Hidroksida $(\mathrm{NaOH})$.

Alat yang digunakan adalah Neraca analitik, mantel penangas, evaporator, desikator, aluminium foil, beaker glass, corong pisah, ball pipet, autoclave, buret, corong, erlenmeyer, gelas ukur, Pengukus, oven, alat pengempa, neraca analitik, mantel penangas, evaporator, desikator, aluminium foil, beaker glass, gelas ukur, pipet volum, pipet mohr, corong pisah, thermometer.

\section{Rancangan Penelitian}

Metode penelitian ini adalah metode expriment. Rancangan yang digunakan adalah Rancangan Acak Lengkap Non Faktorial (RAL Non Faktor) dengan tiga taraf perlakuan terhadap limbah hasil samping (kepala, isi perut, kulit) pada 
ikan baji-baji dengan ulangan sebanyak 3 kali, sehingga terdapat 9 unit percobaan. Parameter yang diamati adalah analisa proksimat tepung ikan meliputi kadar air, kadar abu, protein, lemak, dan karbohidrat. Penjabaran pembahasan melalui metode deskriptif yaitu menggambarkan serta menjelaskan kajian teori yang sifatnya konseptual melalui penelusuran, dan mengumpulkan literatur dari berbagai sumber pustaka, seperti buku, jurnal, artikel dari internet, dan sumber pustaka lainnya yang berkaitan dengan tulisan ini.

\section{Pelaksanaan Penelitian}

Bagan penelitian dilakukan dalam tiga tahap, yaitu: (1) preparasi sampel; (2) pembagian dan pemanfaatan produk hasil samping sebagai tepung ikan dan minyak ikan; (3) analisa komposisi kimia (proksimat). Bagan penelitian dapat dilihat pada gambar 1 .

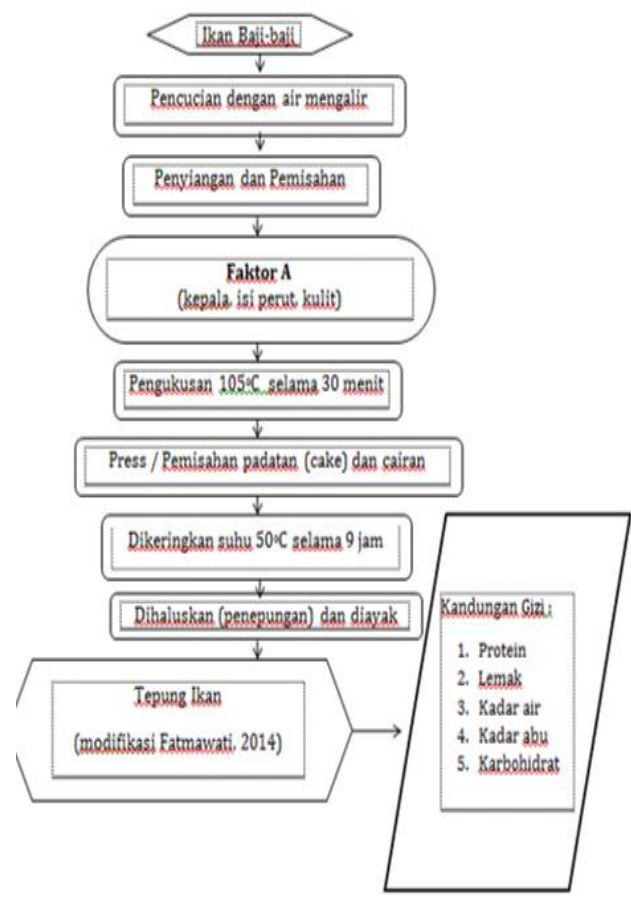

Gambar 1. Rendemen Hasil Tepung Ikan Baji-baji

\section{HASIL DAN PEMBAHASAN}

\section{Analisis Rendemen Proporsi Produk Hasil Samping pada Ikan Baji-baji}

Persentase pada proporsi produk hasil samping (by-product) ikan baji-baji didapatkan dengan membandingkan antara produk hasil samping (by-product) yaitu kepala, kulit, dan tulang terhadap bobot ikan. Persentase hasil perhitungan proporsi produk hasil samping (byproduct) disajikan pada Gambar 1.

\section{Proporsi Bagian Tubuh Ikan Baji-baji}

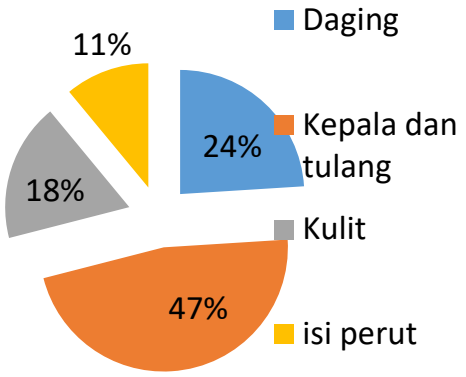

Gambar 2. Proporsi dari Berbagai Bagian pada Ikan Baji-baji

Berdasarkan data yang didapatkan dari Gambar 1 persentase proporsi ikan baji-baji untuk limbah hasil samping (by-product) terdapat 76\% dibandingkan daging 24\%, hasil samping yang terbesar didapatkan pada bagian kepala tulang (47\%) dan Kulit (18\%) dan isi perut bagian badan (11\%). Tingginya nilai persentasi pada proporsi (byproduct) ikan baji-baji memberi peluang dalam pemanfaatannya.

\section{Rendemen Tepung Ikan Baji-baji}

Dalam prinsip zero waste concept melalui penanganan hasil samping dengan memanfaatkan secara optimal. Rendemen menjadi parameter dalam suatu hal yang paling penting untuk mengetahui nilai ekonomis dan efektivitas suatu proses produk atau bahan. Perhitungan rendemen berdasarkan presentase perbandingan antara berat akhir dengan berat awal proses.

Penyusutan bobot pada perlakuan terjadi penyusutan terutama pada badan isi perut, tepung yang dihasilnya $9 \%$ dari 
1 ekor ikan baji-baji. Menurut amiarso (2003) menjelaskan bahwa semakin besar rendemennya maka semakin tinggi pula nilai ekonomis produk tersebut, begitu pula nilai efektivitas dari produk. Rendemen tepung tulang ikan baji-baji disajikan pada Gambar 3.

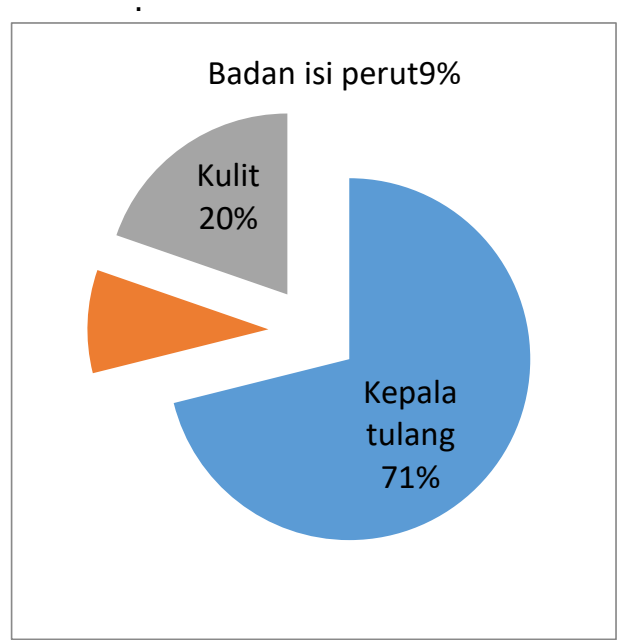

Gambar 3. Rendemen Hasil Tepung Ikan Baji-baji

Hasil rendemen tepung dari produk hasil samping ikan baji-baji yaitu tepung kepala tulang memiliki rendemen lebih banyak $71 \%$ dan tepung badan isi perut 9\% lebih sedikit dari proporsi tepung yang lain. Berdasarkan analisis ragam diketahui terdapat perbedaan yang sangat nyata $(\mathrm{P}<0,01)$ dari ketiga perlakuan pada byproduct ikan baji-baji yang sudah ditepungkan, terdapat perbedaan dalam rendemen hasil tepung yang didapat. Penurunan rendemen tersebut diduga karena adanya faktor komponen non mineral seperti air, protein, dan lemak yang terdapat dalam bahan pangan.

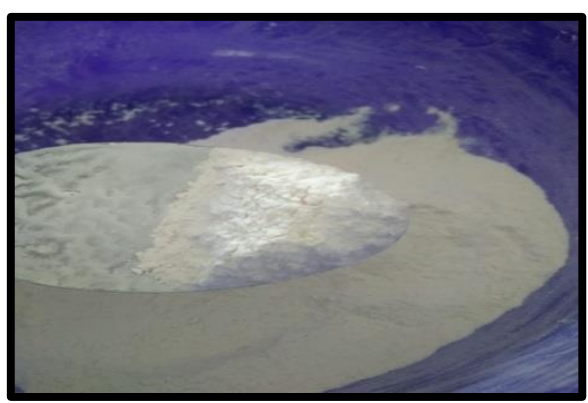

Gambar 4. Tepung Ikan Baji-baji

\section{Kandungan Komposisi Kimia (nutrisi) Tepung Ikan Baji-baji}

\section{a. Kadar Protein Tepung Ikan Baji- Baji}

Tepung yang dihasilkan dari ikan baji-baji berdasarkan hasil pengujiannya masih memiliki nilai protein yang cukup tinggi dengan kadar proteinnya diatas $40 \%$. Berdasarkan hasil analisis ragam yang diperoleh pada perbadingan tepung tulang ikan baji-baji terhadap bagian yang berbeda kepala tulang, badan isi perut, dan kulit diketahui bahwa terdapat perbedaan yang significant antaratepung kepala tulang dan kulit, namun tak berbeda nyata antara kepala tulang dengan badan isi perut. Hasil analisis ragam yang dilakukan terhadap rendemen menunjukkan bahwa perlakuan terdapat ada beda nyata $(\mathrm{P}<0,05)$.

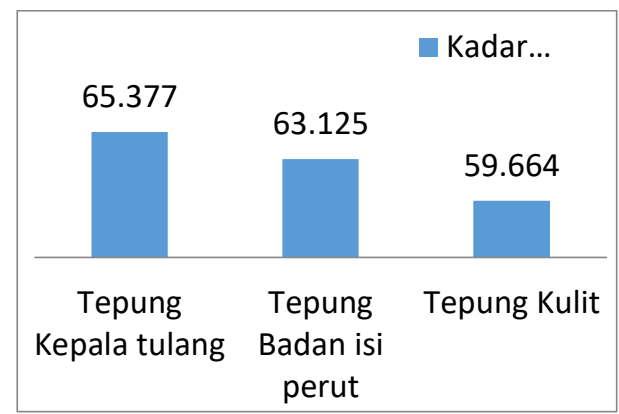

Gambar 5. Kadar Protein Tepung Ikan

Baji-baji

Tepung ikan dari limbah hasil samping memiliki kandungan protein yang sangat baik yaitu tepung kepala 65,377\% dan Tepung kulit memiliki kadar protein yang lebih rendah 59,664\%. Kadar protein tepung tulang ikan baji-baji yang diperoleh lebih baik, berada mendekati nilai kadar protein tepung tulang ikan tuna yang diperoleh dalam penelitian Apriliani (2010) sebesar 33,50\% yang tidak menggunakan metode hidrolisis protein dalam proses pembuatan tepung tulang. Walau demikian, kadar protein hasil penelitian ini masih lebih tinggi dibandingkan kadar protein yang diperoleh Trilaksani (2006) sebesar 
1,29\% pada tepung tulang ikan tuna dengan metode hidrolisis protein.

\section{Kadar Air Tepung Ikan Baji-baji}

Dalam menghasilkan tepung ikan baji-baji yang memiliki kualitas terbaik secara fisik harus memiliki kadar air yang relatif rendah. Tepung ikan baji-baji yang memiliki kadar air yang relatif tinggi mudah mengalami kemunduran mutu. Menurut Mulia (2004) menyatakan bahwa kadar air bahan pangan merupakan jumlah air yang dikandung bahan pangan dan sangat berpengaruh pada mutu dan keawetan pangan.

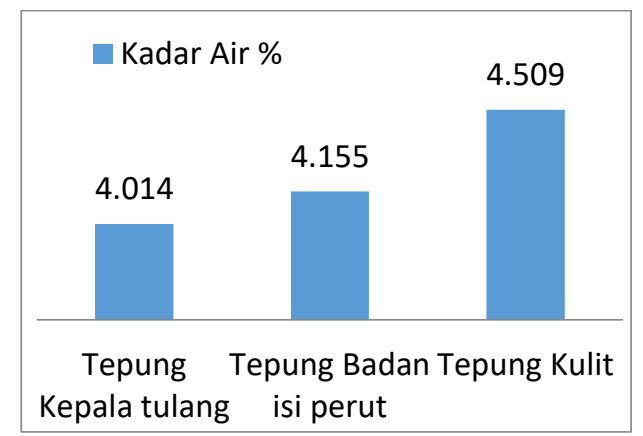

Gambar 6. Kadar Air Tepung Ikan Bajibaji

Dari hasil analisa dan pengamatan kadar air tepung tulang ikan baji-baji disajikan pada Gambar 5, tepung hasil samping ikan baji-baji memiliki kadar air yang cukup rendah dibanding ikan yang lain yaitu tepung tulang kepala 4,014\%. Nilai kadar air tepung kepala lebih rendah dibanding proporsi tepung isi perut dan tepung kulit. Tepung kulit memilki kadar air tertinggi yaitu 4,509\%. Hasil analisis ragam yang dilakukan terhadap kadar air menunjukkan bahwa perlakuan yang diberikan tidak menunjukkan beda nyata $(\mathrm{P}>0,05)$ tidak ada perbedan yang signifikan diantara setiap perlakuan dalam kadar air tepung tulang ikan baji-baji. Tepung tulang ikan baji-baji (Grammoplites scaber) yang dihasilkan mengandung kadar air yang lebih rendah dibandingkan dengan nilai tepung tulang tuna sebesar 5,60\% (Trilaksani ,2006), namun tepung ikan baji-baji jauh lebih tinggi dari tepung tulang nila pada penelitian Hemung (2013), yaitu sebesar 2.46\%. Kadar air tepung tulang ikan baji-baji masih berada pada kisaran standar yang ditetapkan SNI. Berdasarkan Standar Nasional Indonesia (SNI 01-3158-1992), tepung tulang memiliki kadar air maksimal 8\%. Produk dengan kadar air yang rendah akan mempunyai daya awet yang lebih lama.

\section{Kadar Lemak pada Tepung Ikan Baji- baji}

Kualitas tepung ikan baji-baji akan relatif lebih baik jika memiliki kadar lemak yang rendah, karena kadar lemak yang rendah mampu membuat mutu relatif jauh lebih stabil dan tidak mudah rusak.

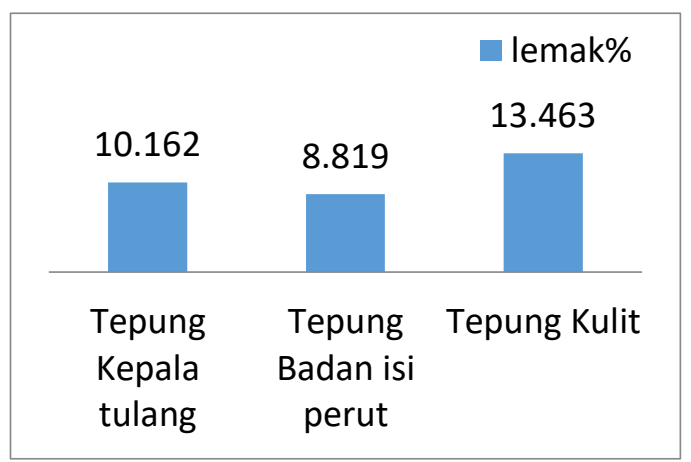

Gambar 7. Kadar Lemak Tepung Ikan Bajibaji

Berdasarkan Gambar 7. Tepung limbah hasil samping memiliki kadar lemak yang tertinggi pada tepung kulit $13,463 \%$ dan tepung badan isi perut memiliki nilai lemak terendah 8,819\%. Menurut Trilaksani (2006) menjelaskan bahwa kadar lemak yang tinggi dapat menyebabkan tepung mempunyai citarasa ikan (fish taste) dan menyebabkan terjadinya oxidative rancidity sebagai akibat oksidasi lemak. Berdasarkan hasil analisis ragam yang dilakukan terhadap kadar lemak pada tepung ikan baji-baji menunjukkan bahwa terdapat perbedaan yang signifikan terhadap masing-masing perlakuan dengan menunjukkan ada beda $(\mathrm{P}<0.05)$ terhadap kadar lemak tepung tulang ikan 
yang diperoleh. Kadar lemak tepung tulang ikan baji-baji diketahui bahwa kadar lemak tepung tulang ikan tersebut memiliki kadar lemak yang lebih rendah sesuai yang diharapkan. Hasil pengamatan kadar lemak tepung tulang ikan baji-baji dapat dilihat Gambar 6 .

Hasil kadar lemak tepung ikan bajibaji ini lebih rendah dibandingkan dengan kadar lemak pada penelitian Hemung (2013) dimana diketahui bahwa kadar lemak tepung tulang nila sebesar $5.82 \%$, namun kadar lemak pada tepung baji-baji memiliki nilai yang tidak jauh beda dibanding dengan tepung tulang tuna (Trilaksani 2006) sebesar $4.13 \%$ dan kadar lemak tepung ikan baji-baji memiliki nilai yang lebih tinggi dibandingkan dengan kadar lemak tepung tulang patin (Apriliani,2010) yang sebesar $2.09 \%$. Sesuai dengan SNI 013158-1992 tepung ikan baji-baji berada mutu II karena kadar lemaknya berada diatas $3 \%$ sesuai syarat mutu I.

\section{Kadar Karbohidrat dan Kadar Abu pada Tepung Ikan Baji-baji}

Dari hasil pengujian Komposisi kimia diketahui bahwa kadar karbohidrat tepung ikan baji-baji relatif cukup tinggi diatas $15 \%$.

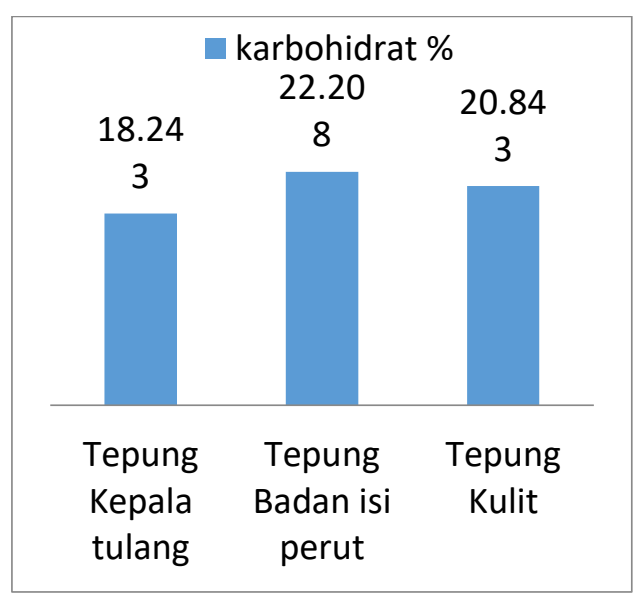

Gambar 8. Kadar Karbohidrat Tepung Ikan Baji-baji

Nilai karbohidrat tepung limbah hasil samping yaitu tepung isi perut memiliki nilai tertinggi $22,208 \%$ dan tepung tulang kepala memiliki nilai terendah $18,243 \%$.

Berdasarkan hasil analisis ragam yang dilakukan terhadap kadar karbohidrat pada tepung ikan baji-baji menunjukkan bahwa terdapat perbedaan yang signifikan terhadap perlakuan dengan menunjukkan ada beda $(\mathrm{P}<0.05)$, namun pada tepung badan isi perut dengan tepung kulit tidak memiliki perbedaan $(P>0,05)$ terhadap kadar karbohidrat tepung tulang ikan yang diperoleh. Kadar karbohidrat tepung tulang ikan baji-baji diketahui bahwa kadar karbohidrat yang lebih rendah sesuai yang diharapkan. Hasil pengamatan kadar karbohidrat tepung tulang ikan baji-baji dapat dilihat Gambar 8.

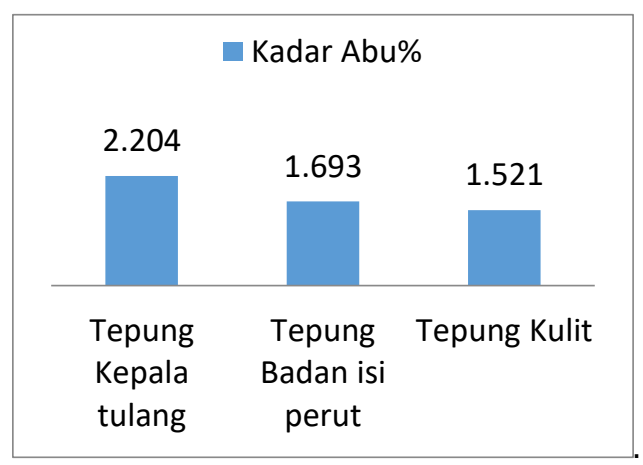

Gambar 9. Kadar Abu Tepung Ikan Bajibaji

Berdasarkan hasil analisis ragam yang dilakukan terhadap kadar abu pada tepung ikan baji-baji menunjukkan bahwa terdapat perbedaan yang signifikan terhadap perlakuan dengan menunjukkan ada beda $(\mathrm{P}<0.05)$ antara tepung kepala tulang dibandingkan yang lainnya, namun pada tepung badan isi perut dengan tepung kulit tidak memiliki perbedaan $(\mathrm{P}>0,05)$ terhadap kadar abu tepung tulang ikan yang diperoleh. Analisis kadar abu bertujuan untuk menentukan kadar abu total dan kandungan masing-masing mineral yang terdapat dalam tepung tulang ikan.

Kandungan abu dalam bahan pangan menunjukkan jumlah bahan 
anorganik yang tersisa setelah bahan organik didestruksi (Sulaeman et al. 1995).

\section{KESIMPULAN}

Pemanfaatan secara konsep zero waste mampu meningkatkan potensi limbah buangan hasil samping menjadi produk yang bernutrisi. Limbah ikan samping dapat diolah menjadi tepung tulang. Adapun hasil pengkajian yang dilakukan yaitu limbah hasil samping (by-product) terdapat 76\% dibandingkan daging $24 \%$, hasil samping yang terbesar didapatkan pada bagian kepala tulang (47\%) dan Kulit (18\%) dan isi perut bagian badan (11\%).

Tingginya nilai persentasi pada proporsi (by-product) ikan baji-baji memberi peluang dalam pemanfaatannya. Hasil rendemen tepung dari produk hasil samping ikan baji-baji yaitu tepung kepala tulang memiliki rendemen lebih banyak $71 \%$ dan tepung badan isi perut $9 \%$ lebih sedikit dari proporsi tepung yang lain.

Kandungan gizi terbaik yaitu protein 65,377\% (tepung kepala), lemak 13,463\% (tepung kulit), kadar air 4,509\% (tepung kulit), kadar abu 2,204 (tepung kepala), dan karbohidrat 22,208\% (tepung isi perut). Dari hasil pengujian disimpulkan bahwa limbah hasil samping ikan baji-baji dapat dimanfaatkan sebagai tepung tulang yang bernilai gizi.

\section{UCAPAN TERIMAKASIH}

Karya ini didukung secara finansial oleh Kementerian Riset, Teknologi, dan Pendidikan Tinggi Republik Indonesia melalui Penelitian Dosen Pemula (PDP) 2019. Para penulis berterima kasih kepada seluruh civitas akademika Program Studi Teknologi Pengolahan Hasil Perikanan Politeknik Tanjungbalai.

\section{DAFTAR PUSTAKA}

Amiarso., 2003. Pengaruh penambahan daging ikan kambing - kambing (Abalistes steilatus) terhadap mutu kerupuk gemblong khas Kuningan Jawa Barat. Skripsi. Bogor: Fakultas Perikanan dan Ilmu Kelautan, IPB.
Apriliani, IS., 2010. Pemanfaatan Tepung Tulang Ikan Patin (Pangasius hypophtalmus) Pada Pembuatan Cone Es krim. Skripsi. Bogor: IPB.

Diana, Ayu dan Ahmad Fauzan Lubis. 2018. Peningkatan Potensi Ikan Baji-baji (Grammoplites scaber) dan Proporsi Bagian Tubuh sebagai Sumber Bahan Baku. Jurnal Teknologi Pangan dan Hasil Pertanian "Agrintech". Volume 2 No.1.e-ISSN 26141213.

http://doi.org/10.30596/agrnt ech.v2i1.2545.

Fatmawati, dan mardiana. 2014.Tepung Ikan Gabus sebagai Sumber Protein (food supplement).Jurnal bionature, volume 15, Nomor 1, April 2014, hlm54-60

Gandotra R, Sharma A, Koul M, Gupta S. 2012. Effect of Chilling and Freezing on Fish Muscle. Journal of Pharmacy and Biological Sciences 2, 05-09

Hemung, B., 2013. Properties of Tilapia Bone Powder and Its Calcium Bioavailability Based on Transglutaminase Assay. International Journal of Bioscience, Biochemistry and Bioinformatics. Vol.3(4)306309. DOI: 10. 7763/IJBBB. 2013. V3.219.

Pamijiati (2009). Pengaruh ekstrak daun selasih (Ocimum basilicum linn) terhadap mutu kesegaran ikan bandeng selama penyimpanan dingin (Chanos chanos Forsk). Skripsi. Semarang : Universitas Diponegoro.

Mulia. 2004. Kajian potensi limbah tulang ikan patin(Pangasius $S p$ ) sebagai alternatif suber kalsium dalam produk mi kering. Skripsi. Bogor:Fakultas Perikanan dan 17 
Ayu Diana,Muhammad Zakiyul fikri/ Agrintech | Jurnal Teknologi Pangan dan Hasil Pertanian 3 (1) 2019, 11-18

Nurjanah., Abdullah, A., Kustiariyah. 2011. Pengetahuan dan Karakterisasi Bahan Baku Hasil Perairan. Bogor: IPB Press

Sulaeman D. 2008. Zero Waste [Prinsip Menciptakan Agro-industry Ramah Lingkungan]. Jakarta: Direktorat Pengolahan Hasil Pertanian.

Trilaksani, W., Salamah E. \& Nabil, M. 2006.Pemanfaatan Limbah Tulang Ikan Tuna (Thunnus sp.)Sebagai Sumber Kalsium
Dengan Metode Hidrolisis Protein. Buletin Teknologi Hasil Perikanan. Vol. 9(2): 34-45

Widyatami, Linda Ekadewi ., Ardhitya Alam Wiguna (2016). Teknologi Pengolahan Ikan Lele secara Zero Waste menjadi Produk Olahan Kerupuk pada Ponpes Raden Rahmat Sunan Ampel di Kabupaten Jember. Seminar Hasil Penelitian dan Pengabdian Masyarakat Dana BOPTN. ISBN : 978-602-14917-3-7 